\title{
PEMBERDAYAAN HUKUM UNTUK MENGUBAH PERILAKU MASYARAKAT PETANI DALAM RANGKA PENINGKATAN SOSIAL EKONOMI MASYARAKAT PETANI
}

Oleh :

\section{Retno Hendrati l'urwaningrum}

\begin{abstract}
To solve of the ineffectiveness of integrated pest control regulation, the law empowerment is likely needed such as firming up the regulation and improving law awareness of the farmers by regulation extension.
\end{abstract}

Keywords : Ineffectiveness, integrated pest control regulation, law empowerment

\section{PENDAHULUAN}

Upaya rekayasa sosial yang dilakukan oleh Pemerintah melalui pemberdayaan hukum guna penerapan teknologi pertanian demi peningkatan sosial ekonomi masyarakat petani telah dilakukan dua kali yang pertama adalah penerapan intensifikasi pertanian, sedang yang kedua adalah penerapan teknologi pengendalian hama terpadu. Rekayasa sosial yang pertama telah berhasil secara memuaskan, sehingga. terjadi perubahan perilaku masyarakat petani secara revolusioner dalam bidang pertanian tersebut. Namun demikian rekayasa sosial yang kedua ternyata tidak begitu berhasil sebagaimana sebelumnya walaupun tidak dapat dikatakan gagal. Dalam hal itu perubahan perilaku yang terjadi pada masyarakat petani tidak terjadi secara revolusioner tetapi secara inkremental, yaitu sedikit demi sedikit, karena ternyata selain terdapat perubahan perilaku sebagaimana diharapkan, masih ada perilaku masyarakat petani yang belum sesuai dengan beberapa ketentuan hukum yang mengatunya.

Oleh karena teknologi pengendalian hama terpadu telah ditentukan sebagai teknologi yang digunakan dalam pelaksanaan kegiatan perlindungan tanaman, sedangkan kegiatannya terdiri dari tiga hal sebagaimana diatur dalam pasal 21 Undang-Undang Nomor 12 Tahun 1992, maka penulis membatasinya pada pelaksanaan kegiatan pengendalian organisme pengganggu tumbuhan.

Schubungan dengan uraian di depan, maka pemerintah dalam upayanya mengubah perilaku masyarakat petani dalam melaksanakan perlindungan tanaman. khususnya pengendalian organisme pengganggu tumbuhan agar menggunakan teknologi 
pengendalian hama terpadu, perlu memperhatikan substansi/materi hukum pasal 20 Undang-Undang Nomor 12 Tahun 1992, khususnya yang berhubungan dengan pasal $21 \mathrm{~b}$ Undang-Undang tersebut. Dalam hal ini perlu diupayakan agar hukum, terutama yang berkaitan dengan pasal-pasal tersebut, dapat menjadi lebih berdaya dan efektif, sehingga upaya rekayasa sosial terhadap masyarakat petani sebagaimana dimaksud di atas dapat berhasil.

Sebagai salah satu langkah penting dalam memberi arah bagi upaya rekayasa sosial melalui pemberdayaan hukum adalah dengan melihat faktorfaktor yang mendorong dan yang menjadi kendala bagi efektifnya (berlakunya) hukum bersangkutan dalam masyarakat yang dituju.

\section{PEMBAHASAN}

\section{Pendorong Efektifitas Hukum Pengendalian Organisme Pengganggu Tumbuhan}

Dalam hal ini terdapat beberapa faktor yang mendorong terjadinya perubahan perilaku masyarakat petani sehingga sesuai dengan Undangundang Nomor 12 Tahun 1992 dan Peraturan Pemerintah Nomor 6 Tahun 1995 yaitu faktor kebiasaan yang timbul akibat penerapan program intensifikasi pertanian yang telah dimulai sejak tahun 1976. Faktor kebiasaan tersebut didasari oleh keyakinan bahwa cara-cara yang dipergunakan dalam intensifikasi pertanian adalah baik dan membawa keuntungan. Selain itu terdapat faktor tanggapan terhadap pengaruh sosial yang muncul karena sugesti serta faktor kepentingan sendiri. Sugesti adalah suatu proses dimana seseorang individu menerima suatu cara penglihatan atau pedoman tingkah laku dari orang lain tanpa kritik terlebih dahulu. Ada beberapa keadaan dan syarat yang memudahkan terjadinya sugesti pada individu manusia, yaitu : karena hambatan berpikir, karena keadaan pikiran terpecah-pecah, karena otoritas, karena mayoritas, karena "will to believe ". Hambatan berpikir dapat dialami oleh sescorang individu yang menjadi bingung karena dihadapkan pada kesulitan-kesulitan hidup yang terlalu kompleks bagi daya tampung pikirannya.

Otoritas pada lapangan (bidang) tertentu atau prestixe sosial yang tinggi yang dimiliki olch seseorang. dukungan mayoritas yang dimiliki oleh seseorang misalnya mengenai pandangan atau ucapannya tersebut akan memudahkan terjadinya sugesti pada individu manusia lainnya. demikian pula seseorang individu yang telah mempunyai sikap pandangan tertentu, tetapi dalam keadaan terpendam, akan lebih mudah menerima sugesti mengenai sikap pandangan tertentu tersebut, karena dalam pribadi individu yang bersangkutan sudah terdapat suatu ketersediaan untuk lebih sadar dan yakin akan hal-hal yang disugestikan itu. Keidaan tersebut dinamakan sugesti karena "will ob heliceve" (karnakeinginan untuk meyakini dirinya).

\section{Kendala Efektifitas Hukum Pengendalian Organisme Pengganggu Tumbuhan}

Adapun faktor yang menjadi kendala bagi terjadinya perubahan perilaku masa petani dalam 
melaksanakan pengendalian organisme pengganggu tumbuhan, sehingga tidak sesuai dengan ketentuan hukum yang mengaturnya, terdapat beberapa faktor, antara lain faktor kebiasaan yang didasari keyakinan dalam penggunaan pestisida secara berjadual adalah baik bagi keberhasilannya dalam mengupayakan panen sayurannya. Bagi para petani pada umumnya pestisida dianggap sebagai "obat" dan merupakan kebutuhan dari tanaman sayuran yang, harus dipenuhi, agar dapat menghasilkan panen yang baik. Sebagaimana terbukti pada awal pelaksanaan intensifikasi pertanian.

Selain faktor tersebut, pada petani menganggap bahwa tanpa penggunaan pestisida secara berjadual, tanaman tidak akan mungkin panen, karena dikhawatirkan akan diserang hama penyakit tanaman. Adapun hama penyakit tanaman yang sangat ditakuti oleh para petani yang menanam bawah merah adalah "bun upas" (kabut), karena jika tanaman sudah terserang kabut tersebut, pucuk--pucuk daun tanaman akan "mlungker" kemudian tanaman mati. Dengan demikian faktor resiko yang terkandung dalam perubahan perilaku yang dikehendaki oleh ketentuan hukum pengendalian organisme pengganggu tumbuhan lebih besar dari pada jaminan sosial yang bisa diusahakan.

Selanjutnya masih ada faktor lain yang menjadi kendala bagi perubahan perilaku masyarakat petani, yaitu gencarnya promosi pestisida yang masuk ke yang menambah keyakinan para petani mengenai khasiat "obat" tanaman.

Sebagaimana kenyataan, walaupun terdapat para petani yang menggunakan pestisida secara berjadual sehingga melakukan pelanggaran atas pasal 60 ayat (1) e dan ayat (2) e Undang-Undang Nomor 12 Tahun 1992, tetapi tidak pernah dilakukan penegakan hukumnya. Bahkan penerapan pasal 17 Peraturan Pemerintah Nomor 6 Tahun 1995 juga belum dilaksanakan.

Hal ini juga merupakan faktor kendala bagi terjadinya perubahan perilaku masyarakat petani untuk dapat sesuai dengan ketentuan hukum yang mengaturnya.

Disamping faktor-faktor tersebut, ternyata terdapat faktor yang sangat penting, yaitu faktor belum terbentuknya kesadaran hukum para petani secara utuh mengenai hukum yang mengatur mengenai pengendalian organisme pengganggu tumbuhan. Bahkan mereka belum mengetahui bahwa terdapat ancaman hukuman bagi mereka yang melanggar larangan pasal 22 ayat (1) Undang--Undang Nomor 12 Tahun 1992 jo pasal 60 ayat (1) e dan ayat (2) e Undang-Undang Nomor 12 Tahun 1992. Mereka tidak mengetahui akan hak dan kewajiban mereka dihadapan hukum berkenaan dengan pelaksanaan pengendalian organisme pengganggu tumbuhan.

Berikut ini akan disampaikan pula faktor yang berupa aspek ekonomi yang merupakan kendala bagi terjadinya perubahan perlakuan masyarakat petani agar dapat sesuai dengan ketentuan hukum yang 
mengatur pengendalian organisme pengganggu tumbuhan.

Sebagaimana diketahui, bahwa bekerjanya mekanisme pasar menghasilkan harga. Apabila pada suatu tingkat harga tertentu kuantitas barang yang diminta melebihi yang ditawarkan oleh penjual, maka harga barang akan naik. Sebaliknya apabila kuantitas barang yang ditawarkan tersebut lebih banyak dari pada yang diminta, maka harga akan turun. Disebutkan pula, bahwa kecenderungan kenaikan harga diakibatkan oleh penurunan kuantitas barang yang di tawarkan. Keadaan pasar yang demikian seringkali menyebabkan para petani dengan sengaja melanggar aturan pola tanaman yang benar (waktu tanam yang tepat). Mereka ingin menikmati untung yang besar jika dapat panen pada waktu "panen raya" yang mana harga komoditi yang bersangkutan justru menjadi tinggi, karena kelangkaan komoditi tersebut yang disebabkan misalnya oleh banjir setiap tahun di daerah lain. Dalam hal ini berarti mereka telah melanggar pasal 20 ayat (1) jo. Pasal 21 huruf B. Undang-Undang Nomor 12 Tahun 1992 jo. Pasal 9 ayat (1) Peraturan Pemerintah Nomor 6 Tahun 1995 Pedoman Rekomendasi Pengendalian hama penyakit Tanaman Pangan, tentang pola tanam.

Perbuatan pelanggaran tersebut biasanya telah dicegah oleh teman atau kerabat petani yang akan melakukannya, dengan memperingatkan agar tidak melakukannya, karena pasti tidak panen Perbuatan pelanggaran tersebut menyebabkan pelakunya melakukan pelanggaran yang lain, yaitu dengan melakukan aplikasi pestisida tanpa pemantauan terlebih dulu dan secara berjadual, sejak saat tanaman muncul ke permukaan tanah, sampai saat siap di panen (tua). Dengan demikian berarti petani tersebut telah melanggar pasal 20 ayat (1) Pasal 21 huruf b Undang-Undang Nomor 12 Tahun 1992 jo. Pasal 9 Peraturan Pemerintah Nomor Tahun 1995.

\section{Pemberdayaan Hukum Pengendalian Organisme Pengganggu Tumbuhan}

Faktor-faktor kendala di atas menyebabkan ketidaksesuaian antara perilaku masyarakat petani dalam melaksanakan pengendalian organisme pengganggu tumbuhan dengan hukum yang mengaturnya.

Mengingat bahwa salah satu tujuan diundangkannya Undang-Undang Nomor 12 Tahun 1992 tentang Sistem Budidaya Tanaman adalah untuk meningkatkan sosial ekonomi masyarakat petani, maka upaya pemberdayaan hukum melalui penegakan hukum yang mengatur pengendalian organisme pengganggu tumbuhan tersebut harus dilaksanakan, di samping mengoptimalkan faktor pendorong dan mengantisipasi faktor kendala sebagaimana tersebut di atas. Menurut Satjipto Rahadrjo, terhadap ketentuan hukum yang berfungsi sebagai sarana mengubah perilaku masyarakat, seharusnya penegakan hukumnya juga berfungsi sebagai sarana perubahan tersebut. Ketentuan hukum yang mengatur 
masalah pengendalian OPT pada dasamya mengajak masyarakat Indonesia pada umumnya dan masyarakat petani di Indonesia pada khususnya untuk mencapai suatu keadaan dimana tanaman terlindung dari serangan Organisme Pengganggu Tumbuhan (OPT) tetapi baik manusia, kemampuan sumberdaya alam maupun kelestarian lingkungan hidup tetap terjaga (selamat) dan dapat memperhatikan serta meningkatkan produksi budidaya tanaman.

Sebagaimana norma-norma sosial lainnya, norma (ketentuan hukum tentang pengendalian OPT juga disertai dengan sanksi-sanksi bagi pelanggarannya. Sanksi-sanksi tersebut diatur dalam pasal 60 ayat 91) dan ayat (2) Undang-U-ndang Nomor 12 Tahun 1992 tentang Budidaya tanaman, dimana perbuatan yang melanggar pasal 60 ayat (1) tersebut dianggap sebagai kejahatan dan pelakunya dapat dikenai sanksi pidana penjara paling lama 5 (lima) tahun dan denda paling banyak $\mathrm{Rp}$. $250.000 .000,00$ (dua ratus lima puluh juta rupiah). Sedangkan perbuatan yang melanggar ayat (2) pasal 60 tersebut dinamakan pelanggaran, dan pelakunya dapat dikenai sanksi pidana penjara paling lama 12 (dua belas) bulan atau denda paling banyak

Rp. 50.000.000,00 (lima puluh juta rupiah).

Demikian pentingnya masalah penggunaan teknologi PHT tersebut, sehingga sanksi yang diancamkan bagi pelanggar ketentuan yang mengaturnya begitu berat. Namun demikian sebagaimana telah ditetapkan dalam ketentuan TAP
MPR-RI Nomor II/MPR/1993 tentang Garis-garis Besar Haluan Negara, bagian bidang hukum, point d, penerapan hukum dan penegakan hukum dilaksanakan secara tegas dan lugas tetapi manusiawi berdasarkan rasa keadilan dan kebenaran dalam rangka mewujudkan ketertiban dan kepastian hukum, meningkatkan tertib sosial dan disiplin nasional yang mantap dan dinamis.

Di samping melalui penerapan sanksi pidana terdapat beherapa cara yang dapat ditempuh untuk mengupayakan penegakan hukum pengendalian OPT, antara lain melalui pasal 17 Peraturan Pemerintah Nomor 6 Tahun 1975. Pada pasal tersebut dinyatakan bahwa Kepala Desa, Camat. Mantri Tani, Dinas Pertanian atau instansi teknis lainnya dapat meminta laporan secara rutin setiap periode tertentu atau sewaktu-waktu sesuai keperluan, kepada perorangan atau badan hukum yang menggunakan pestisida dalam rangka pengendalian organisme pengganggu tumbuhan yang mempunyai dampak terhadap kesehatan manusia, schagaimana dimaksud dalam pasal 15 Peraturan Pemerintah Nomor 6 Tahun 1995. Cara lain yang ditempuh untuk upaya penegakan hukum pengendalian OPT adalah dengan melakukan pengawasan terhadap penggunaan pestisida dalam rangka pengendalian organisme pengganggu tumbuhan. Sebagaimana diatur dalam pasal 20 Peraturan Pemerintah Nomor 6 Tahun 1995. Pengawasan tersebut dilakukan olch menteri yang bertanggungjawab di bidang Budidaya tanaman yang 
menunjuk petugas pestisida. Dalam hal penunjukan petugas tersebut, Menteri Pertanian mengeluarkan Surat Keputusan Menteri Nomor 356/Kpts/TP.270/ 1985 tentang pengawasan Pestisida.

Berkenaan dengan pengawasan pestisida tersebut, maka Gubernur Kepala Daerah Tingkat I dengan dibantu oleh Kepala Kantor Wilayah Departemen Pertanian mengkoordinasikan kegiatan pengawas pestisida yang dilakukan oleh pengawas pestisida tingkat propinsi dan Bupati Kepala Daerah Tingkat II dengan dibantu oleh Kepala Dinas Pertanian Kabupaten Daerah Tingkat II mengkoordinasikan kegiatan. pengawasan pestisida yang dilakukan oleh para pengawas pestisida tingkat kabupaten/kotamadya. Hal ini sesuai pasal 9 ayat (2) Surat Menteri Pertanian Nomor 536/Kpts/TP.270.17/ 1985. Dalam melaksanakan pemberdayaan hukum, khususnya sebagai sarana rekayasa sosial/perubahan perilaku masyarakat, selain penegakan hukum masih terdapat beberapa hal yang harus dilaksanakan oleh Pemerintah sebagai aparatur hukum, yaitu berkenaan dengan empat langkah sistematis dari Adam Podgorecky. Dalam hal ini telah dilakukan langkah memahami nilai-nilai yang ada dalam masyarakat, yaitu den-an mengutamakan pelaksanaan Program Nasional Pengendalian Hama Terpadu pada daerah/ real intensifikasi pertanian. Sedangkan jenis Sekolah lapang Pengendalian Hama Terpadu (SLPHT) disesuaikan dengan jenis tanaman yang paling banyak ditanam dl wilayah yang bersangkutan.
Pengutamaan pelaksanaan Program Nasional PIIT pada areal intensifikasi, berarti Pemerintah sebagai aparatur hukum telah memilih masyarakat petani yang menganggap pestisida scbagai obat tanaman. yang dapat mengobati dan mencegah tanaman dari serangan hama/penyakitnya. Masyarakat petani pada area intensifikasi telah menganggap (menilai) bahwa hama dan penyakit tanaman sebagai pengganggu yang harus diberantas tuntas.

Selanjutnya pelaksanaan Program Nasional PHT merupakan upaya dari pemerintah sebagai aparatur hukum melakukan komunikasi hukum Adapun komunikasi hukum yang dilakukan dengan masyarakat petani berupa masuknya informasi mengenai Teknologi Pengendalian Hama Terpadu, untuk pelaksanaan pengendalian organisme pengganggu tumbuh ke dalam masyarakat yang bersangkutan.

Pada waktu mengikuti SL-PHT sayur tersebut, kelompok Tani diperkenalkan serta dilatih untuk menggunakan teknologi PHT dalam pelaksanaan perlindungan tanaman sayuran khusus tanaman kentang. Dalam kegiatan tersebut diperoleh perbedaan hasil panen sebanyak $10 \%$ yaitu petak PHT menghasilkan

$880 \mathrm{~kg}$ dan petak lokal $800 \mathrm{~kg}$. dengan hasil penjual Rp. 264.000,00 dari petak PHT dan Rp. 240,000,00 dari pelak lokal. Sedangkan biaya usaha tani petak PIIT dan Rp. 277.000 .00 petak lokal. Oleh 
karenanya maka perbedaan keuntungan yang diperoleh menjadi jauh lebih besar dari p-erbedaan hasil penjualan, yaitu 143,3375 dimana keuntungan petak PHT adalah Rp. 16.050,00 petak lokal mengalami kerugian sebesar Rp. 37,000,00. Pada pelatihan SLPHT sayuran tersebut nyata diperlihatkan (karena dialami sendiri peserta pelatihan keuntungan menggunakan teknologi PHT).

Agar hukum berlaku efektif, salah satu syarat yang harus dipenuhi adalah komunikasi hukum. Istilah komunikasi berarti pengiriman pesan atau berita antara dua orang atau lebih sehingga pesan itu dapat dipahami. Dengan demikian komunikasi hukum dapat diartikan sebagai pengiriman pesan mengenai hukum sehingga pesan tersebut dapat dipahami oleh masyarakat yang bersangkutan.

Keberhasilan melakukan komunikasi hukum pada suatu masyarakat, menimbulkan adanya kesadaran hukum masyarakat tersebut, yaitu kesadaran hukum dalam arti pengetahuan bahwa suatu perilaku tertentu diatur oleh hukum (arti kedua). Sedangkan arti kata kesadaran hukum yang pertama adalah nilai-nilai yang terdapat dalam diri manusia mengenai hukum yang ada. Kesadaran hukum merupakan semacam jembatan yang menghubung antara ketentuan hukum dengan perilaku hukum anggota masyarakat yang bersangkutan.

Dalam rangka mengusahakan agar masyarakat mempunyai kesadaran hukum / dalam rangka meningkatkan kesadaran hukum masyarakat, pemerintah Indonesia melaksanakan program Penyuluhan Kesadaran Hukum, melalui Keputusan Kehakiman Republik Indonesia No. M 05 PR $07-$ 0-, tanggal 6 Agustus 1988 tentang pembentukan dan Pembinaan Keluarga Sadar yang selanjutnya disebut dengan Kadarkum serta peraturan Menteri Kehakiman Republik Indonesia No. 05-PR-08-10 tahun 1998 tanggal 6 Agustus 1988 tentang Pola Pemantapan Penyuluhan Hukum.

Kadarkum berfungsi scbagai wadah perhimpunan masyarakat yang berkesadaran hukum, dan bertugas meningkatkan kesadaran hukum yang tinggi hagi para anggotanya dan masyarakat pada umumnya. Untuk menjadi anggota Kadarkum tidak ada paksaan, tapi sesuai Kadarkum, dilakukan dengan melaksanakan penyuluhan hukum, yaitu suatu kegiatan untuk meningkatkan kesadaran hukum masyarakat berupa penyampaian dan penjelasan hukum kepada masyarakat dalam suatu informal agar setiap anggota masyarakat mengetahui dan memahami apa yang menjadi hak, kewajiban dan wewenangnya, sehingga tercipta sikap dan perilaku berkesadaran hukum, yaitu selain mengetahui, memahami menghayati sekaligus mematuhi. Mentaati hukum sesuai pasal 1 point b. Peraturan Menteri No. 05 PR 08-10 tahun 1998.

Ada dua sasaran yang hendak dicapai melalui program penyuluhan hukum, yaitu :

1. Masyarakat memahami aturan-aturan hukum, hak serta kewajiban menurut hukum dan prosedur 
hukum dalam menyelesaikan masalah-masalah yang dihadapi.

2. Masyarakat mentaati dan memahami hukum atas kesadaran sendiri tanpa paksaan atau ancaman dari siapapun.

Adapun cara penyuluhan dapat diberikan secara langsung, yaitu penyuluhan hukum berhadapan dengan masyarakat yang disuluh, dapat berdialog dan bersambung rasa, misalnya ceramah, diskusi, temu wicara, simulasi dan lain-lain. Di samping itu penyuluhan hukum dapat diberikan secara tidak langsung yaitu penyuluhan hukum dapat diberikan secara tidak langsung, yaitu penyuluhan hukum dapat diberikan secara tidak langsung yaitu penyuluhan hukum tidak berhadapan dengan masyarakat yang disuluh, tetapi melalui media perantara, misalnya radio, TV, film, bahan bacaan dan lain-lain.

\section{DAFTAR PUSTAKA}

Abidin Bembi, Petunjuk Studi Lapangan PHT Sayuran, Bawang Merah, Cabai, Kacang Panjang, Kentang, Kubis Dan Tomat, Cet. Ke-3, Program Nasional Pengendalian Hama Terpadu Departemen Pertanian, Jakarta, 1996.

Anonim, Petunjuk Umum Pelaksanaan Pengawasan Pestisida, Direktorat Jenderal Pertanian Tanaman Pangan, Direktorat Perlindungan Tanaman Pangan, Jakarta, 1988.

Anonim, Petunjuk Teknis Pengelolaan
Lingkungan Dalam Pembangunan Tanaman Pangan dan Hortikultura, Direktorat Jenderal Tanaman Pangan dan Hortikultura, Direktorat Bina Program, Jakarta, 1994.

Anonim, Surat Keputusan Menteri Pertanian Nomor 390/Kpts/TP.600/4/1994 Tentang Penyelenggaraan Program Nasional Pengendalian Hama Terpadu, 1994.

Bagian Proyek Pengendalian Hama Terpadu (PHT) Jawa Timur Tahun Anggaran 1997/1998 Petunjuk Teknis Pelaksanaan Kegiatan Dinas Pertanian Tanaman Pangan Daerah, Propinsi Daerah Tingkat 1 Jawa Timur.

Chaeruddin, OK, Sosiologi Hukum, Cet. Perdana, Sinar Grafika, Jakarta , 1991.

Gerungan. W.A., Psikologi Sosial, Edisi Kedua, ('et, Ketigabelas, PT. Liresco, Bandung, 1996.

Rahadjo, Satjipto, Hukum dan Perspektif Sosial, Penerbit Alumni, Bandung. 1981.

Sastrosiswojo, Sudarwohadi, Petunjuk Lapangan (Petlap) PHT Sayuran, Bawang Merah, Cabai, Kacang Panjang, Kentang, Kubis dan Tomat, Cet. Ke-3, Program Nasional Pengendalian Hama Terpadu, Departemen Pertanian. Jakarta, 1996.

Sudarsono, Buku Pengantar Ekonomi Mikro, 1983. 